\title{
Meta
}

Journal des traducteurs

Translators' Journal

\section{Transition, Inherent Possession and the French Pronominal Construction}

\section{Aloysius Ajang Enang}

Volume 39, numéro 3, septembre 1994

URI : https://id.erudit.org/iderudit/002709ar

DOI : https://doi.org/10.7202/002709ar

Aller au sommaire du numéro

Éditeur(s)

Les Presses de l'Université de Montréal

ISSN

0026-0452 (imprimé)

1492-1421 (numérique)

Découvrir la revue

Citer cette note

Enang, A. A. (1994). Transition, Inherent Possession and the French Pronominal Construction. Meta, 39(3), 529-533. https://doi.org/10.7202/002709ar
Résumé de l'article

L'auteur étudie le fonctionnement de deux des différents types de verbes pronominaux en français (les pronominaux transitifs et les pronominaux possessifs) afin de pouvoir dégager des règles de traduction vers l'anglais. Il conclut que les pronominaux transitionnels se rapportent généralement à l'état du sujet et sont suivis d'une préposition; ils se traduisent principalement par un verbe copule accompagné d'un participe passé ou d'un adjectif. De leur côté, les pronominaux possessifs entraînent toujours une entité animée et une de ses parties ; ils se traduisent par un verbe simple et la partie de l'entité impliquée est déterminée par un adjectif possessif. 
pronominaux possessifs) afin de pouvoir dégager des règles de traduction vers l'anglais. Il conclut que les pronominaux transitionnels se rapportent généralement à l'état du sujet et sont suivis d'une préposition; ils se traduisent principalement par un verbe copule accompagné d'un participe passé ou d'un adjectif. De leur côté, les pronominaux possessifs entraînent toujours une entité animée et une de ses parties; ils se traduisent par un verbe simple et la partie de l'entité impliquée est déterminée par un adjectif possessif.

\section{INTRODUCTION}

The French pronominal verb has always presented difficulties in translation because of its often ambiguous and generally multifonctional nature. A few researchers have studied this problem only to conclude that this group of verbs could be translated into English in many ways. Thus Vinay and Darbelnet (1967: 133) isolated four categories of French pronominals: "a) la voix pronominale réfléchie, b) la voix pronominale réciproque, c) la voix pronominale qui rend subjective une réalité objective, et d) la voix pronominale d'habitude." They add (p. 187) that "seules les catégories a) et b) se traduisent littéralement en anglais. Les autres aboutissent, soit à des verbes neutres, soit à des passifs."

Unfortunately their work is limited to a simple enumeration of translation possibilities. They make no attempt at providing clues for distinguishing one type of pronominal construction from another, a move which would have helped translators to determine which verb is likely to be translated in what way.

In our unpublished M.A. essay, ${ }^{1}$ we conducted a methodical analysis of French pronominal constructions based on their renditions into English. This study yielded nine categories which we labelled 1) Reflexive, 2) Reciprocal, 3) Passive, 4) Neutral, 5) Collective, 6) Intrinsic, 7) Subjective representation, 8) Transitional, and 9) Possessive. This paper is limited to a discussion of the last two categories, namely Transitional and Possessive constructions.

\section{TRANSITIONAL PRONOMINAL CONSTRUCTIONS}

The French pronominal verb is generally expected to express an action performed by the subject on itself, $e . g$.:

1) Le garçon se regarde dans le miroir.

n The boy is looking at himself in the mirror.

\section{TRANSITION, INHERENT POSSESSION AND THE FRENCH PRONOMINAL CONSTRUCTION}

\section{Résumé}

L'auteur étudie le fonctionnement de deux des différents types de verbes pronominaux en français (les pronominaux transitifs et les
However certain pronominal verbs tend to express a change of state, whether abrupt or gradual. As such they can be likened to predicative adjectives. Predicative adjectives are those adjectives that are virtually restricted to predicative position (predicate - verb), e.g.:

2) Paul is AFRAID of the dark. 
They are opposed to attributive adjectives which appear in attributive position, e.g.:

3) This is a LAZY boy.

Quirk and Greenbaum (1973: 123) point out that predicative adjectives "are more like verbs and adverbs" and "tend to refer to a (possibly temporary) condition rather than to characterize." This aptly describes the functions of some French pronominal verbs. Consider the following sentences:

4) Le garçon se fâche.

1) The boy gets angry.

5) La situation se complique.

f The situation becomes complicated.

In the above sentences the verbs se facher and se compliquer do not express an action performed by the subject upon itself; rather they express a change. Thus se fâcher expresses a change of mood (an emotional change) and se compliquer, a change in the way the action progresses (a situational change). Similarly we may have:

6) Mes jambes s'engourdissent.

n) My legs are becoming numb.

7) Pierre se fatigue.

) Pierre is getting (becoming) tired.

In both examples 6) and 7) s'engourdir and se fatiguer express physical changes.

These verbs, however, do not characterize the noun phrases, as would attributive adjectives such as small, bad, or good in "a small boy," "a bad situation," or "a good teacher." Rather, they refer to a change in the subjects' condition(s). Such French pronominal verbs are usually translated into English by means of the verb to be or any other intensive verb such as to seem, to become, or to get, plus an adjective for some, e.g.:

se fâcher : to get angry

s'endurcir: to become tough

$s$ 'engourdir : to become numb

and a past participle for others, e.g.:

se compliquer : to become complicated

s'ennuyer: to be bored

se fatiguer : to get tired

This second group of transitional pronominals can be confused very easily with passive pronominals which are also translated into English by means of the auxiliary to be plus a past participle. Distinguishing these transitional pronominals from passive pronominals, therefore, becomes difficult. However certain features can be helpful:

That the participle can have an adjectival function is well-known, but it is not often easy to see the difference between the passive form and the descriptive form of the participle. Quirk and Greenbaum (1973: 140) point out that:
[...] the difference between the adjective and the participle is not clear-cut, and lies in the verbal force retained by the latter [...]; the verbal force is explicit for the -ed form when a by agentive phrase with a personal agent is present, indicating the correspondence to the active form of the sentence $[\ldots]$

This is as true for French as it is for English. Consider the following sentences:
8) Les bottes se nettoient. (Passive)
) Boots can be cleaned.
9) Paul se fatigue. (Transitional)
) Paul is getting (becoming) tired.

If we attempt to transform the above sentences into non-pronominal passive sentences we have:
10) Les bottes sont nettoyées.
I) (The) boots $\left\{\begin{array}{l}\text { are } \\ \text { have been } \\ \text { can be }\end{array}\right\}$ cleaned.
11) Paul est fatigué.
1) Paul is tired.

The intervention of an agent must be postulated in 10) which is derived from 8 ). The sentence might be expanded to

10') Les bottes sont nettoyées par le cordonnier.

$$
\Lambda \text { (The) boots }\left\{\begin{array}{l}
\text { are } \\
\text { have been } \\
\text { can be }
\end{array}\right\} \begin{aligned}
& \text { cleaned by the } \\
& \text { shoemaker. }
\end{aligned}
$$

Such a postulation is not possible in 11) which is derived from 9). A corresponding expanded sentence might be:

11') Paul is tired from working long hours.

It could not be:

*Paul is tired by somebody.

Many verbs in this category can be translated by simple verbs or verbal phrases as well as by the construction AUX plus ADJ / PAST PARTICIPLE:

12) Jean s'étonne de la performance de Marc.

$D_{\text {Jean }}\left\{\begin{array}{l}\text { is amazed } \\ \text { marvels }\end{array}\right\}$ at Marc's performance.

13) Le professeur s'intéresse aux abeilles.

) The professor $\left\{\begin{array}{l}\text { is interested } \\ \text { takes an interest }\end{array}\right\}$ in bees.

Passive pronominals, on the other hand, are usually translated into English by means of the passive form only.

A large number of transitional verbs can or must take complementation and are usually followed by prepositions such as à, de, en / dans:

14) se préoccuper de $X$ : to be concerned with/about X 
15) s'intéresser à $X$ : to be interested in $X$

16) s'engager dans $X$ : to become involved in $X$

Finally the verbal adjective is distinguishable from the participle proper by the fact that modification by the intensifier very is possible for the former and impossible for the latter. Hence we can have:

17) Le garçon est très fâché.

h) The boy is very angry.

but we cannot have

18) *Les bottes sont très nettoyées.

0 (The) boots $\left\{\begin{array}{l}\text { are } \\ \text { have been } \\ \text { can be }\end{array}\right\}$ very cleaned.

One would therefore expect the co-occurrence of the intensifier very and a by agentive phrase containing a personal agent to produce an unacceptable sentence. This is true in most cases, e.g.:

19) *Les bottes sont très nettoyées par le cordonnier.

n*(The) boots $\left\{\begin{array}{l}\text { are } \\ \text { have been }\end{array}\right\} \begin{aligned} & \text { very cleaned } \\ & \text { by the shoe- } \\ & \text { maker. }\end{aligned}$

20) *Le garçon est très fâché par son ami.

i) *The boy is very angry by his friend.

However, with the -ed participle forms of certain English verbs, there appears to be increasing acceptance of this co-occurrence:

21) The man was very offended by the policeman.

But there is no problem of co-occurrence if the agent is non-personal:

22) I am very disturbed by your attitude.

In examples 21) and 22), however, we may assume that much was omitted and attribute this to ellipsis. Indeed, the following forms seem more acceptable:

23) The man was very much offended by the policeman.

24) I am very much disturbed by your attitude.

\section{POSSESSIVE PRONOMINAL}

\section{CONSTRUCTIONS}

The pronominal construction is also used to indicate inherent possession. Let us consider the following sentences:

1) Pierre se brosse les dents.

n Pierre brushes his teeth.

2) Le garçon se lèche les doigts.

n The boy licks his fingers.

3) Marie se tord le cou pour regarder au plafond.
) Marie twists her neck to look at the ceiling.

We notice two things from the translations of the above sentences:

(i) the French pronominal verbs have been translated by means of simple English verbs;

(ii) there has been a translation shift at the level of the noun determiners within the object noun phrases from definite articles to possessive adjectives:

1) les dents: his teeth

2) les doigts : his fingers

3) le cou: her neck

This shift from article to possessive adjective is a good example of Catford's category shifts (Catford 1965: 79).

How can we account for this phenomenon?

The answer appears to lie in the underlying structures of the French constructions. It has been suggested by some grammarians like Sandfeld (1965) and Kayne (1975) that structures like

4) mon livre; son ami; ta maison

) my book, his friend, your house

are derived from adnominal à phrases such as

5) le / un livre à moi - mon livre

n) the / a book of mine - my book

6) l' / un ami à lui-son ami

) the / a friend of his - his friend

7) la / une maison à toi - ta maison

) the / a house of yours - your house

This derivation is made through a transformation which Kayne calls "POSS" (for possessive). Kayne (1975: 196) adds that such a "transformation, [...] that moves the object of $a$ into the position of the article in definite NPs [...]"' is applicable only to the pronouns moi, toi, soi, lui, elle, nous, vous, eux, elles. In fact such adnominal $a$ phrases occur, to a limited extent, in standard French. It is not unusual to come across sentences like the following examples from Kayne (1975: 196):

8) Elle a rencontré un ami hier soir.

9) Elle a rencontré un ami à Jean hier soir.

However the POSS transformation is possible only with the pronouns listed above. Hence we may have:

10) un ami à moi - mon ami une amie à elle - son amie

but we cannot have

11) un ami à Jean — Jean ami

Using the POSS transformation, we can account for such pronominal constructions as the ones in 
examples 1 to 3 . Assuming that these examples were derived from the following underlying structures:

12) *Pierre brosse les dents à lui. * Le garçon lèche les doigts à lui. * Marie tord le cou à elle.

we may derive, through the POSS transformation, the following constructions:

13) Pierre brasse ses dents. Le garçon lèche ses doigts. Marie tord son cou.

In French, however, sentences like the ones in 13) are much less frequent than 1) to 3) although, from a purely grammatical point of view, there seems to be nothing wrong with them since similar structures are accepted:
14) Je lave mes habits.
I) I wash my clothes.
15) Le garçon lèche sa crème glacée.
n) The boy licks his ice cream.

However, French prefers an article as noun determiner in constructions involving an animate entity and a part of that entity. In that usage the article reflects inherent possession, Guillemin-Flescher's propriété inhérente (Guillemin-Flescher 1981: 219). The phenomenon is also observed in non-pronominal constructions like

16) François a les mains dans les poches.

1) François has his hands in his pockets.

There are instances, however, when the possessive adjective is used as noun determiner in non-pronominal constructions involving an animate entity and one or more of its parts. This generally has the effect of particularizing the noun so determined. Very often such a noun is followed by a qualifier:

17) Le garçon lève son doigt blessé.

1) The boy raises his wounded finger.

18) Jeanne met sa main malade dans sa poche.

f) Jeanne puts her hurting hand in her pocket.

Such usage is impossible in a possessive pronominal construction:

$$
\text { 19) *Le garçon se lèche son doigt malade. }
$$

We may therefore draw the following conclusions:

(i) possessive pronominal constructions always involve an animate entity and a part of that entity;

(ii) the part of the entity involved in the construction generally functions as complement:

19) Je me lave LA TÊTE.

i) I wash MY HAIR

20) Elle se met le bébé SUR LE DOS.

f) She puts the baby ON HER BACK. (iii) the part of the entity involved in the construction takes an article for noun determiner. Such an article reflects inherent possession;

(iv) the pronoun $S E$ in such constructions functions as the clitic representative of the adnominal $a$ complement of the part of the entity involved in the construction:

21) Je lave la tête À MOI. - Je ME lave la tête.

22) Marie tord le cou À ELLE. - Marie SE tord le cou.

In translating possessive pronominal constructions:

(i) the French pronominal verb corresponds to a neutral or simple English verb;

(ii) the part of the entity involved in the construction is determined by a possessive adjective.

\section{CONCLUSION}

It would appear therefore that the French pronominal verb is used to express, among other things, 1) transitional states and 2) inherent possession

Transitional pronominals generally refer to a (usually temporary) state of the subject. They are, in most cases, followed by prepositions like à, de, en/dans, in constructions in which they can or must take complementation. They are generally translated into English with an intensive verb and a past participle or an adjective.

Possessive pronominals, on the other hand, always involve an animate entity and a part of that entity. The noun determiner for the part of the entity involved in the construction is an article and reflects inherent possession. The pronoun $S E$ is a clitic representative of the adnominal $\grave{a}$ complement of the part of the entity involved in the construction and is coreferential to the subject noun phrase. In their English translation the verb is simple and the part of the entity involved is determined by a possessive adjective.

ALOYSIUS AJANG ENANG

Economic and Social Council, Yaounde, Cameroon

\section{Note}

1. ENANG, A. A.: "The Translation of the French Reflexive Verbs into English", M.A. Thesis, University of Montreal, May 1986.

\section{REFERENCES}

CATFORD, J. C. (1965): A Linguistic Theory of Translation, London, Oxford University Press.

GUILLEMIN-FLESCHER, J. (1981): Syntaxe comparée du français et de l'anglais, Paris, OPHRYS.

KAYNE, R. S. (1975): French Syntax: The Transformational Cycle, Cambridge, Massachusetts, MIT Press.

QUIRK, R. and S. GREENBAUM (1973): A University Grammar of English, London, Longmans.

SANDFELD, K. (1965): Syntaxe du français contemporain, I: les pronoms, Paris, Champion. 
VINAY, J.-P. et J. DARBELNET (1958) : Stylistique comparée du français et de l'anglais, Paris, Marcel Didier (édition 1967). 